\title{
Simple methodological approach for assessing microbial mineralization rates in an aqueous anaerobic medium
}

\author{
Abordagem metodológica simples para avaliação das taxas de mineralização microbiana \\ em meio aquoso anaeróbio
}

\section{Marcela Bianchessi da Cunha-Santino ${ }^{1,2 *}$ (D) and Irineu Bianchini Junior ${ }^{1,2}$ (D)}

${ }^{1}$ Departamento de Hidrobiologia, Universidade Federal de São Carlos - UFSCar, Rodovia Washington Luiz, Km 235, CP 676, CEP 13565-905, São Carlos, SP, Brasil

${ }^{2}$ Programa de Pós-graduaçáo em Ecologia e Recursos Naturais, Universidade Federal de São Carlos - UFSCar, Rodovia Washington Luiz, Km 235, CP 676, CEP 13565-905, São Carlos, SP, Brasil

*e-mail: cunha_santino@ufscar.br

Cite as: Cunha-Santino, M.B. and Bianchini Junior, I. Simple methodological approach for assessing microbial mineralization rates in an aqueous anaerobic medium. Acta Limnologica Brasiliensia, 2021, vol. 33, e202.

\begin{abstract}
The aim of this study was to propose and discuss a simple manometric method to quantify the emission rates of gases resulting from the microbial anaerobic mineralization of organic resources, as leaves, thin branches, and macrophyte detritus. The proposed method can be used under laboratory conditions. The method consists of using a water pressure gauge attached to the reaction flask. The incubations were prepared with samples of water from Paranapanema River and Typha domingensis, the experiment lasted 9.8 months. The procedures for preparing the incubations are presented in detail, as well as the calculations for the conversion of the volumetric measurement into carbon mass (i.e., daily rate of carbon gas emissions). According to the results obtained from T. domingensis mineralization assays it was possible to demonstrate that, numerous events related to mineralization could be adequately addressed (e.g., the heterogeneous detritus composition). The results of this method were quite convergent with those obtained in kinetic experiments (used as a reference) after the $30^{\text {th }}$ mineralization day, suggesting the use of this method mainly for mediumand long-term experiments. As exemplified by T. domingensis incubations, this method is particularly valuable for the systemic comparison of the several organic resources mineralization and for the primary measurement of the main parameters involved (e.g., reaction rates constants). This method combined with other short-term experiments can greatly improve the understanding of the cycling of organic resources in aquatic environments.
\end{abstract}

Keywords: water pressure gauge; decomposition; carbon cycling; aquatic environment; greenhouse gases.

Resumo: O objetivo deste estudo foi propor e discutir um método manométrico simples para quantificar as taxas de emissão de gases resultantes da mineralização anaeróbia microbiana de recursos orgânicos, como folhas, galhos finos e detritos de macrófitas. O método proposto pode ser usado em condições de laboratório. O método consiste na utilização de um manômetro de água acoplado ao frasco de reação. As incubaçóes foram preparadas com amostras de água do rio Paranapanema e Typha domingensis, o experimento durou 9,8 meses. Os procedimentos para a preparação das incubaçóes são apresentados em detalhes, bem como os cálculos para a conversão da medição volumétrica em massa de carbono (ou seja, taxa diária de emissóes de gás de carbono). De acordo com os resultados obtidos da mineralização de $T$. domingensis foi possível demonstrar que, inúmeros eventos relacionados 
à mineralização podem ser adequadamente tratados (por exemplo, a composição heterogênea dos detritos). Os resultados deste método foram bastante convergentes com os obtidos em experimentos cinéticos (usado como referência) após o $30^{\circ}$ dia de mineralização, sugerindo a utilizaçáo deste método principalmente para experimentos de médio e longo prazo. Como exemplificado com incubaçóes de T. domingensis, este método é particularmente valioso para a comparação sistêmica da mineralização de vários recursos orgânicos e para a medição primária dos principais parâmetros envolvidos (por exemplo, constantes de reaçáo). Este método combinado com outros experimentos de curto prazo pode melhorar muito a compreensão da ciclagem de recursos orgânicos em ambientes aquáticos.

Palavras-chave: método manométrico; decomposição; ciclo do carbono; ambiente aquático; gases de efeito estufa.

\section{Introduction}

Mineralization is a key process that determines the magnitude of organic matter stored in hydric soils and sediments, and the amount of greenhouse gas emissions (Heitkamp et al., 2012; Chapman et al., 2019). This process is mostly driven by microbial heterotrophic metabolism (i.e., fungi, bacteria, and archaea activities). Simultaneously with the mineralization, the humification acts to transform a fraction of the plant residues into stable organic matter or humus (Dalmagro et al., 2017). In aquatic systems it prevails in the sediments although they can also occur in the water column. The main variables that modulate this process are: (i) temperature, (ii) oxygen availability, (iii) redox potential, (iv) detritus composition (e.g., lignin, cellulose, and pectins), (v) $\mathrm{pH}$, vi) salinity, (vii) nutrient availability, (viii) prevalence of associated biological groups and (ix) functional capacity of the microbial community (Megonigal et al., 2004; Cunha-Santino \& Bianchini Júnior, 2015; Yan et al., 2018; Yarwood, 2018).

In the inner layers of sediments, anoxic conditions usually prevail, leading to the predominance of anaerobic catabolism. Thus, in this environment, organic matter is mineralized associated with processes such as denitrification, sulfate reduction and fermentation (Reddy \& DeLaune, 2008). Due to the composition of organic resources, the main gaseous emissions from anaerobic mineralization include carbon compounds, carbon dioxide and methane (Philben et al., 2020). The knowledge of decomposition rates is essential to describe fluxes of carbon and other elements in natural systems (Saunders, 1976; Swift et al., 1979; Sanderman \& Amundson, 2004). In particular, to reach the decomposition rates, in situ (e.g., litter bags technique) or in vitro incubations are used. In situ incubations are highly recommended (Bärlocher, 2005a, b), but usually do not allow an accurate assessment of detritus mineralization once, in addition to catabolism (chain of enzymatic reactions), the mass loss also occurs due to dissolution and comminution (Swift et al., 1979). In turn, incubations under controlled conditions (i.e., laboratory experiments) allow the assessment of dissolution and mineralization. However, such incubations lose information due to the selection of organisms and maintenance of simplified environmental conditions (Bärlocher, 1997; Silva et al., 2011). Due to the methodological limitation, decomposition can be achieved by exclusive experiments to describe specific processes.

Owing to the prospects for climate change, greenhouse gas emissions have been the subject of annual national inventories, and a starting point for long-term simulations that aim to describe the climate changes associated with the increases in carbon dioxide, nitrous oxide, and methane in the terrestrial atmosphere (IPCC, 2014, 2019). In addition, the knowledge of the biochemical routes associated with this process allows an in-depth assessment of carbon balances and other elements in aquatic environments (Steinberg, 2003). For this purpose, this study suggests a simple method to evaluate the gas release rates associated to the decomposition of organic resources with specific interests (such as: detritus of aquatic plants, leaves and other types of organic matter added to aquatic environments from wetlands, and riparian regions). The proposed technique can be handled under controlled conditions (i.e., the laboratory environment).

\section{Materials and Methods}

\subsection{The manometric method}

The proposed manometric method was inspired in that designed by Ohle (1972) and suggested for the IBP program (Techniques for the assessment of microbial production and decomposition in freshwater). This method is quite simple and presented low cost, providing a high relation between benefit and cost. It is particularly useful for measuring, over time, the 
potential of different kinds of detritus as sources of greenhouse gas emissions (e.g., carbohydrates, macrophyte specimens, and sediments; Bianchini Júnior et al., 1997; Bianchini Júnior \& Antonio, 2000; Cunha-Santino et al., 2010). As well, to describe the effects of environmental variables (e.g., phosphorus, and organic nitrogen concentrations) over the mineralization rates and its yields (Antonio \& Bianchini Júnior, 2000).

The method consists in using a water pressure gauge attached to the reaction flask (Figure 1). The pressure gauge comprises a graduated pipette and a glass tube connected by a flexible plastic tube. At the end of the glass tube, a bidirectional adapter connects the plastic tube that connects the bottle to the pressure gauge. The rubber stopper of the bottle is connected to the flexible tube by a disposable syringe needle (e.g., insulin syringe). Some parts of this system (i.e., plastic tube, two-way adaptor) are found in the gravitational parenteral infusion set.

For a glass bottle with volume ca. 1.0 liter, it is indicated to include 4.0 to $5.0 \mathrm{~g}$ (in dry mass basis - DM) of the organic resource (e.g., aquatic plant tissue, leaves, and litter). Resources can be pre-ground; nevertheless, it is suggested that the particles are not very small (i.e., fine powder), because the increase in the specific surface enhances the reaction rates, interfering with the yields of mineralization and of the humic substances synthesis (Bianchini Júnior \& Cunha-Santino, 2006). To the water sample from a previously selected site, a drop of inoculum with indigenous microorganisms must be added to stimulate the biochemical oxidations process (Green et al., 2010). The inoculants were obtained from cultures maintained under anaerobic condition, prepared with sediment and water from the environments considered in the assays, and at the selected temperature. If feasible, before the beginning of the experiment the water sample must be bubbled with nitrogen to avoid the availability of dissolved oxygen or reduce its concentration. If it is not possible, considering the proportions proposed (4-5 $\mathrm{g}$ DM of resource per liter), and the deoxygenation rates constants related with this type of detritus, the anaerobiosis will be established in hours (at $\approx 23$ ${ }^{\circ} \mathrm{C}$ ); Fonseca et al. (2014); Passerini et al. (2016). To avoid light interferences during the experiment (e.g., photo-oxidation, and primary production), the reaction flask must be maintained in the dark, wrapped with aluminum foil. When preparing the experiment, the headspace of the bottle must be avoided to maximize the effect of dissolving
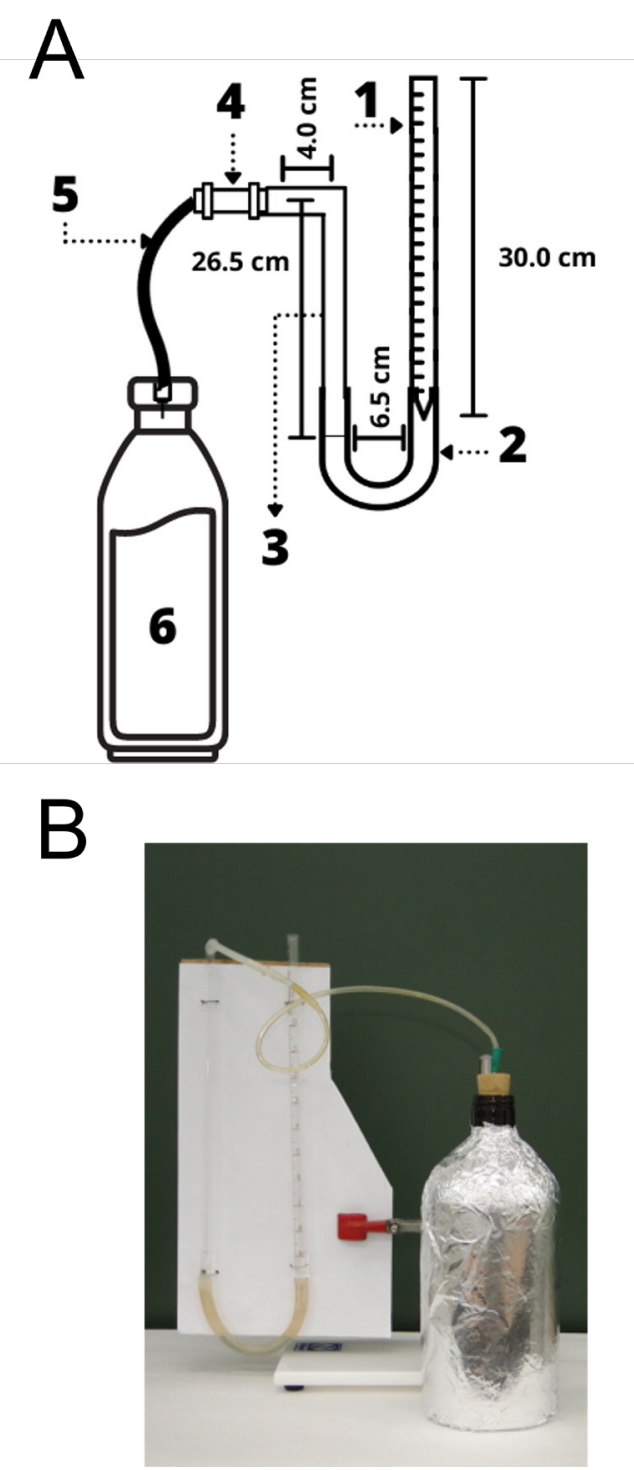

Figure 1. (A) The manometric system to evaluate the daily mineralization rates, and its components: 1) Graduated pipette (vol. $10 \mathrm{ml}$ ); 2) Flexible plastic tube (internal diameter: $0.5 \mathrm{~cm}$ ); 3) Glass tube (external diameter: 0.5 cm); 4) Two ways plastic adapter*; 5) Transparent flexible plastic tube (internal diameter ca. $1 \mathrm{~mm})^{*}$; 6) Reagent bottle (volume: 1 liter). $\left.{ }^{*}\right)$ components present in the gravitational parenteral infusion set. (B) Picture of the manometer attached to the reaction flask.

gases; thus, after the saturation concentration is obtained, the gas readily will generate pressure on the manometer. Before preparing incubations, make sure your manometric systems do not contain leaks that would necessarily lead to an underestimation of the results. It is important to maintain the flask at a steady temperature to avoid changes in metabolic rates and gas saturation concentrations throughout the experiment (Langmuir, 1997; Sanderman \& Amundson, 2004). 


\subsection{The mass balance and mathematical modeling}

For the mass balance formulation, it is indicated that the carbon content of the particulate resource and the carbon concentrations (organic and inorganic) of the water samples are determined at the beginning and at the end of the experiment. Another information that can improve the mass balance at the end of the experiment is the determination of the leaching potential of the selected organic resource (it notifies the magnitude of the refractory particulate material, as well as the mineralization rate constant of the dissolved organic carbon). The $\mathrm{pH}$ determination in the end of experiment also assists the mass balance computation of the carbonate speciation (Langmuir, 1997). Knowing the number of the experimental period (in days) $(\Delta t)$ and with the information of the mass balance (initial and final organic carbon contents), it is possible to deduce the global mineralization rate constant $(\mathrm{k})$, and the half-time $\left(t^{1 / 2}\right)$ of the organic resource that is being evaluated. For this, the long-established exponential model (Jenny et al., 1949) was used (Equations 1 and 2). In the case of knowing the leaching potential and the content of refractory particulate compounds, it is possible to assign the mineralization rates of labile and refractory compounds, increasing the detail and complexity of the kinetic model (CunhaSantino et al., 2016).

$$
k=\frac{\ln \left(W_{t} / W_{0}\right)}{\Delta t}
$$

where: $\mathrm{W}_{\mathrm{t}}=$ detritus mass at a given time $(\mathrm{t})$; $\mathrm{W}_{0}=$ detritus mass in the beginning $(\mathrm{t}=0) ; \mathrm{k}=$ rate constant $\left(\mathrm{d}^{-1}\right)$ for the process.

$t_{1 / 2}=\frac{\ln (0.5)}{-k}$

As gases are produced inside the bottle (e.g., $\mathrm{CO}_{2}, \mathrm{CH}_{4}, \mathrm{H}_{2} \mathrm{~S}$, and $\mathrm{N}_{2}$; Reddy \& DeLaune, 2008) due to the organic resource mineralization, the water inside the plastic tube is displaced and will rise the water column inside the pipette. The mineralization rates will, therefore, be proportional to the volumes added inside the graduated pipette. After reading, the system is balanced again by disconnecting the hose from the manometer (through the two-way adapter). For a better accuracy, it is recommended to adopt daily measurements, because negative rates (elements absorption) occur (Cunha-Santino et al., 2016).
The total inorganic carbon (TIC) from mineralization was calculated by the difference between the initial $\mathrm{C}$ contents of resources and the remaining organic carbon measured at the end of the experiment (Equation 3; Cunha-Santino \& Bianchini Júnior, 2015). The total concentration of $\mathrm{C}_{-}$gas (i.e., $\mathrm{CO}_{2}+\mathrm{CH}_{4}$ ) is estimated by the difference between TIC and remaining (final) concentration of dissolved inorganic carbon (DICf); thus, the mineralized carbon is equal TIC and can be estimated by adding DICf to C_gas (TIC = C_gas + DICf); Cunha-Santino et al. (2016). However, to use the C_gas emission daily rate (C_gasDR; $g$ $\left.\mathrm{d}^{-1}\right)$ as a temporal proxy of mineralization, including the amount of dissolved inorganic carbon, it is necessary establish the proportionality between the total displaced volume (sum of the positive values of volume daily rates; $\Sigma$ vol_gasDR; $\mathrm{ml} \mathrm{d}^{-1}$ ) and the quantity of mineralized carbon (TIC; g), obtained at the end of the experiment. Thus, it is possible to calculate the daily rates as a function of the volume (milliliter) for the carbon (Equation 4). By the Equation 4, it is assumed that the total displaced volume will be mainly proportional to $C_{-}$gas. This association is based on the high prevalence of carbon in detritus composition over other elements (e.g., $\mathrm{N}, \mathrm{S}$; Little, 1979) that will be also released as gases (e.g., $\mathrm{N}_{2}, \mathrm{~N}_{2} \mathrm{O}$, and $\mathrm{H}_{2} \mathrm{~S}$ ) during decomposition under anaerobic condition (Megonigal et al., 2004).

$$
T I C=(P O C i+D O C i)-(P O C f+D O C f)
$$

$C_{-} g a s D R=\left(v o l \_g a s D R\right) \times \frac{T I C}{\sum v o l \_g a s D R}$

where: POCi = particulate organic carbon of resource $(\mathrm{g})$; DOC $\mathrm{i}=$ initial content of dissolved organic carbon of incubation $(\mathrm{g})$; POCf $=$ organic carbon content of remaining particulate detritus (g); DOCf = dissolved organic carbon of incubation at the end of the experiment $(\mathrm{g})$; TIC = total amount of inorganic carbon, owing the mineralization (g); C_gasDR $=$ C_gas daily rate on carbon basis $\left(\mathrm{g} \mathrm{d}^{-1}\right)$; vol_gasDR $=$ C_gas on volume basis $\left(\mathrm{ml} \mathrm{d}^{-1}\right) ; \Sigma$ vol_gasDR = sum of positive values of vol_gasDR (accumulated volume of water displacement during the experiment); $\mathrm{ml}$.

\subsection{Case study}

To illustrate the use of this method, the results of mineralization of the emergent aquatic macrophyte Typha domingensis Pers. (cattail) were used (CunhaSantino et al., 2016). Two incubations were 
maintained under anaerobic condition by bubbling nitrogen (ca. $10 \mathrm{~min}$ ) before starting the experiment, until the dissolved oxygen concentration reached zero $\mathrm{mg} \mathrm{L}^{-1}$. In each decomposition bottle, $5.0 \mathrm{~g}$ (on dry mass basis) of plant fragments were added to $1.0 \mathrm{~L}$ of sample water of Paranapanema River $\left(22^{\circ}\right.$ $56^{\prime} 36.3^{\prime \prime} \mathrm{S}$ and $\left.50^{\circ} 27^{\prime} 57.3^{\prime \prime} \mathrm{W}\right)$ filtered in $0.45 \mu \mathrm{m}$ membrane (Millipore). Filtration was performed to remove the effect of coarse particles from the water samples on the composition of the organic resource (in this case, T. domingensis). The water sampling occurred 1 day before the beginning of experiment. During transportation, no preservative substances were added to the water sample. The flasks were maintained in the dark at a room temperature $\left(23.3 \pm 1.8{ }^{\circ} \mathrm{C}\right)$. For 293 days the daily rates of gas evolved (or consumed) were measured using the manometric method (Figure 1). The length of the experimental period (ca. 10 months) was due to the predominance of refractory fractions (ca. 80\%) of the T. domingensis detritus, and the magnitude of its decomposition rate (CunhaSantino \& Bianchini Júnior, 2006). Using this procedure, the volume of released (or expended) gases was quantified by shifting the water column of low-pressure gauge. After determining the gas daily rates, the gases produced in the incubations were purged to avoid pressurization. At the end of the experiment, the $\mathrm{pH}$ was measured by potentiometry ( $\mathrm{pH}$-meter Digimed, model DMPH-2). The DOC and dissolved inorganic carbon (DIC) were determined by combustion/non-dispersive infrared gas analysis method (Shimadzu analyzer, model 5000A; precision: 0.1 to $1.0 \mathrm{mg} \mathrm{L}^{-1}$ and internal standards: sodium carbonates $\left(\mathrm{NaHCO}_{3}\right.$ and $\mathrm{Na}_{2} \mathrm{CO}_{3}$, proportion $1.65: 1 \mathrm{w} / \mathrm{w}$ ) and potassium hydrogen phthalate); (DOCi, DICi, DOCf, and DICf; Equation 3). The remaining detritus at the end of the experiment were oven-dried $\left(45^{\circ} \mathrm{C}\right)$ and gravimetrically quantified. The carbon contents of particulate detritus (POCi and POCf; Equation 3) were quantified using a Carlo Erba $\mathrm{CHN}$ elemental analyzer (model EA1110), calibrated with external standards (L-cystine, sulphalamine and 2,5-bis[tertbutyl-2-benzoxazolyl] thiophene).

To compare the mass loss from the decomposition of $T$. domingensis calculated from this method (manometric) and from an anaerobic kinetic experiment under similar conditions, the study carried out by Cunha \& Bianchini Jr. (2006) was utilized. From this procedure, it was possible to compare the remaining organic material (POC+DOC) established from the manometric method and recorded by the kinetic experiment.

\section{Results and Discussion}

The carbon budget from $T$. domingensis mineralization after 293 days is presented (Table 1). It is possible to verify that the remaining organic carbon was predominantly in particulate form (93.9\%). At the end of experiment, the dissolved organic and inorganic carbon concentrations were similar. After measured the total dissolved inorganic carbon, the dissolved $\mathrm{CO}_{2}$ concentration was calculated using the relationships derived from the equilibrium constants of the dissociation reactions. According to the $\mathrm{CO}_{2}$ dissolution potential at $\mathrm{pH} 6.01$, and $23.3^{\circ} \mathrm{C}$, the final concentration of inorganic carbon $\left(91.73 \mathrm{mg} \mathrm{L}^{-1}\right)$ was higher than the saturation concentration of that gas $\left(\approx 480 \mu \mathrm{g} \mathrm{L}^{-1}\right.$; Bashkin, 2002), and according to the $\mathrm{pH}$ and temperature of the experiment, it was possible specify (Bowie et al., 1985; Langmuir, $1997)$ that the predominant form of dissolved inorganic carbon (69.1\%) was "free $\mathrm{CO}_{2}$ " (dissolved $\left.\mathrm{CO}_{2}+\mathrm{H}_{2} \mathrm{CO}_{3}\right)$, followed by bicarbonate $(30.9 \%)$; Table 1. Whereas the detritus of this macrophyte is

Table 1. Mass balance (average values and in carbon basis) of the Typha domingensis mineralization.

\begin{tabular}{|c|c|c|c|c|c|c|c|c|}
\hline $\begin{array}{l}\text { POMi } \\
\text { (g) }\end{array}$ & $\begin{array}{c}\mathrm{Ci} \\
(\%)\end{array}$ & $\begin{array}{l}\text { POCi } \\
\text { (g) }\end{array}$ & $\begin{array}{l}\text { POMf } \\
\text { (g) }\end{array}$ & $\begin{array}{l}\mathrm{Cf} \\
(\%)\end{array}$ & $\begin{array}{l}\text { POCf } \\
\text { (g) }\end{array}$ & $\begin{array}{c}\mathrm{DOC} \\
\left(\mathrm{mg} \mathrm{L}^{-1}\right)\end{array}$ & $\begin{array}{c}\text { DIC } \\
\left(\mathrm{mg} \mathrm{L}^{-1}\right)\end{array}$ & $\begin{array}{c}\text { TDC } \\
\left(\mathrm{mg} \mathrm{L}^{-1}\right)\end{array}$ \\
\hline 5.038 & 50.23 & 2.530 & 2.677 & 47.32 & 1.267 & 82.73 & 91.73 & 174.45 \\
\hline $\begin{array}{c}\text { TOCf } \\
\text { (g) }\end{array}$ & $\begin{array}{c}\mathbf{k} \\
\left(\mathbf{d}^{-1}\right)\end{array}$ & $\begin{array}{l}\text { DOC } \\
(\%)\end{array}$ & $\begin{array}{l}\text { DIC } \\
(\%)\end{array}$ & $\begin{array}{l}\text { TDC } \\
(\%)\end{array}$ & $\mathrm{pH}$ & $\begin{array}{c}\text { Free } \mathrm{CO}_{2} \\
(\%)\end{array}$ & $\begin{array}{c}\mathrm{HCO}^{-}{ }^{-} \\
(\%)\end{array}$ & $\begin{array}{l}\mathrm{CO}{ }^{3} \\
(\%)\end{array}$ \\
\hline 1.349 & 0.002 & 3.27 & 3.63 & 6.89 & 6.01 & 69.1 & 30.9 & 0.0 \\
\hline
\end{tabular}

$\mathrm{POMi}=$ initial amount of particulate organic matter; $\mathrm{POMf}=$ final amount of particulate organic matter; $\mathrm{Ci}=$ carbon content of $\mathrm{POMi} ; \mathrm{Cf}=$ carbon content of $\mathrm{POMf} ; \mathrm{POC} i=$ initial amount of particulate organic carbon; $\mathrm{POCf}=$ final amount of particulate organic carbon; DOC = dissolved organic carbon concentration in the end of experiment; TOCf $=$ final amount of total organic carbon $(=\mathrm{POCf}+\mathrm{DOC}) ; \mathrm{DIC}=$ dissolved inorganic carbon concentration in the end of experiment; TDC = DOC + DIC; Free $\mathrm{CO} 2=$ percentage of dissolved $\mathrm{CO} 2+\mathrm{H} 2 \mathrm{CO} 3$ (carbon acid) in the DIC; HCO3- = percentage of bicarbonate in the DIC; $\mathrm{CO} 3==$ percentage of carbonate in the DIC; $\mathrm{k}=$ mineralization rate constant (Equation 1). Percentages were calculated with reference to POCi (100\%). 
chemically homogeneous (without discriminating labile or refractory fractions or particulate and dissolved organic matter), the global mineralization rate indicates that the half-time of this organic resource ( $T$. domingensis) is 323 days, in an anaerobic aqueous medium. The final concentration of DIC corresponded to $7.77 \%$ of the total mineralized carbon (TIC $=1.181 \mathrm{~g}$; equivalent to $46.7 \%$ of the initial carbon content); and the sum of the daily rates of gas formation ( $\Sigma$ vol_gasDR) was $196.22 \mathrm{ml}$.

According to the results of TIC (g) and $\Sigma$ vol_gasDR $\left(\mathrm{ml} \mathrm{d}^{-1}\right)$, the empirical value of the TIC/ $\left(\sum\right.$ vol_gasDR $)$ ratio used to convert daily rates in $\mathrm{ml}$ to $\mathrm{C}\left(\mathrm{g} \mathrm{d}^{-1}\right)$ (Equation 4$)$ is 0.006 . Using the relationship between $\Sigma$ vol_gasDR (x) and TIC (y) obtained from 11 mineralization experiments in which this method was applied (CunhaSantino et al., 2016), the following equation was deduced: TIC $=0.0046$ X $\Sigma$ vol_gasDR; $\mathrm{r}^{2}=0.94$ (TIC in $\mathrm{g}$ and $\Sigma$ vol_gasDR in $\mathrm{ml} \mathrm{d}^{-1}$ ). Thus, if necessary, this linear relationship can replace Equation 4 previously proposed. However, when adopting it, it must be considered that the constant (TIC/ $\sum$ vol_gasD) can over or underestimate the value of the daily carbon rate. For example, the value obtained from the $T$. domingensis mineralization $(0.0060)$ was $32 \%$ higher than this ratio; in this case, using 0.0046 would underestimate the rate. On the other hand, the value 0.0046 can be applied throughout the experiment for a preliminary monitoring of carbon rates, until the mass balance is carried out at the end. Regardless of the resource composition, these results are consistent; pointing out a direct relationship between the volumes displaced and mineralized carbon. Thus, this method can be successfully used for long-term comparison of the decomposition of different detritus, providing clearly the order of magnitude of mineralization rates for each resource. Due to the high reaction rates (i.e., dissolution and oxidation of labile carbon), in the short term, the decomposition tends to generate intense detritus mass losses, according to the original composition of the resource. The leaching DOC, in general, has mass loss rates at intermediate values, and the refractory carbon fractions (i.e., lignocellulosic matrix) displayed low values of mass loss rates (Bianchini Júnior, 2003). These events define a multicompartmental kinetic model (Heitkamp et al., 2012). For this reason, decomposition experiments tend to have a heterogeneous distribution of sampling points, having much of the sampling at the beginning.
Thus, the maximum time of the experiment is basically directed by the refractory characteristics of the resource, and environmental conditions. For example, the time to observe evident loss of mass in the decomposition of $T$. domingensis is greater than found for the composed samples of leaves (e.g., from the forest, and sugarcane and soybean crops), as the refractory fractions have (in anaerobic condition) a half-time of approximately 290 days (CunhaSantino \& Bianchini Júnior, 2006), while those of leaves 60 days (aerobic condition); Bianchini Júnior \& Cunha-Santino (2011).

By using C_gasDR as proxy, in Figure 2A are presented the average temporal change of mineralization rates of $T$. domingensis. In the beginning of the mineralization, it was possible to verify the occurrence of negative values. It is due to the prevalence of elements uptake by microorganisms over the mineralization (releasing). There are also several null values showing that
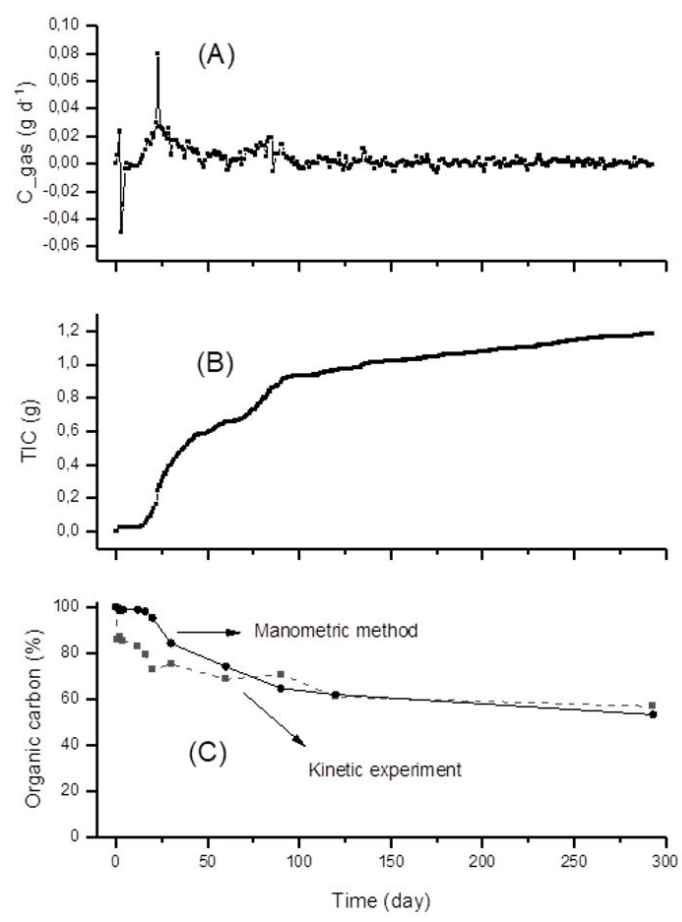

Figure 2. (A) Temporal variations of C_gas daily rate (C_gasDR; $\mathrm{g} \mathrm{d}^{-1}$ ) during mineralization of Typha domingensis under controlled conditions (dark and $23.3 \pm 1.8^{\circ} \mathrm{C}$ ); Cunha-Santino et al. (2016). (B) Kinetic of C_gas during the mineralization of Typha domingensis under controlled conditions (dark and $23.3 \pm 1.8^{\circ} \mathrm{C}$ ); Cunha-Santino et al. (2016). (C) Remaining organic material (POC+DOC) from the decomposition of Typha domingensis established from the manometric method and recorded by the kinetic experiment (Cunha-Santino \& Bianchini Júnior, 2006). 
there is some delay for the prevalence of gases releasing; this results from the predominance of dissolution at the beginning of the experiment, until the gases reached saturation concentrations, from this period displacements in the water column of the manometer were observed. The highest value was registered on the $23^{\text {rd }}$ day, $0.08 \mathrm{~g} \mathrm{C} \mathrm{d}^{-1}$; in the sequence, the values tended to decrease continuously, tending to zero. When integrating the positive values (emission; Equation 4 ) it is possible to observe that during the first 2 weeks there were practically no emissions; however, after this period, until the $100^{\text {th }}$ day, there was intense generation and release of gases. Comparing the integrated results with the mass balance performed on the last day of the experiment (Table 1), it was possible to convert (post hoc) the results obtained in $\mathrm{ml} \mathrm{d}^{-1}$ to $\mathrm{C}\left(\mathrm{g} \mathrm{d}^{-1}\right)$ properly. Thus, it is possible to describe the microbial activities realistically. According to the Shapiro-Wilk test, daily rates were not normally distributed (at the 0.05 level); thus, the Kruskal-Wallis test was used to compare the temporal variation of rates between incubations. The post hoc Dunn's multiple comparison test did not show any difference between the daily rates of incubations or between the daily rates and their respective averages $(\mathrm{p}<0.05)$. Also regarding to the repeatability between incubations, at the end of the experiment, the mass losses of the coarse particulate material were equivalent (47.1 and 46.6\% in bottle 1 and 2, respectively). The final dissolved carbon concentrations were also close in both incubations (DIC: 94.3 and 89.1; DOC: 66.6 and 98.9; TDC: 160.9 and $\left.188.0 \mathrm{mg} \mathrm{L}^{-1}\right)$. Consequently, the amounts of the remaining fractions of organic carbon (dissolved + particulate) were also comparable (1.32 and $1.37 \mathrm{~g}$ ).

The kinetic of $T$. domingensis mineralization (inorganics formation; proxy C_gas) is presented in Figure 2B; it was obtained by integration (sum) of positive values of $\mathrm{C}_{-}$gasDR. Through this approach it is possible to verify that in approximately 80 days a large part (64\%) of the material that would be mineralized (in 293 days) had already been converted. This kinetics indicates the presence of heterogeneous detritus composition, i.e., the presence of labile and refractory compounds. In this context, using the data of mass loss from the T. domingensis decomposition experiment under similar conditions (Cunha-Santino \& Bianchini Júnior, 2006), it was possible to evaluate that about $21 \%$ of the detritus are constituted by labile compounds (including soluble and insoluble fractions), and $79 \%$ by refractory compounds (i.e., ligno-cellulosic fractions), with half-times of 22 and 429 days, respectively. This structural heterogeneity enables the mineralization of plants to generate distinct temporal alterations in aquatic systems, with the beginning of the process being the greatest alterations (e.g., increase in DOC concentrations, color, and dissolved oxygen demands). In turn, detritus with low mineralization rates tend to store and subsidize the synthesis of humic substances (Sanderman \& Amundson, 2004).

Figure 2C shows the mass loss (POC + DOC) kinetics from the $T$. domingensis decomposition according to two different methods: the kinetic experiment (used as a reference), and the manometric determination. In the degradation of this resource, it appears that the methods were strongly equivalent from the $30^{\text {th }}$ day. The losses that occurred in the initial stages were underestimated by the manometric method $\left(r^{2}: 0.77\right)$. These underestimations were due to the required time for the dissolution of gases and elements in the reaction flask to occur, which ended up causing delay in recording the gas formation. However, after the reaction flask of the manometric method reached chemical equilibrium, the two methods showed great convergence $\left(r^{2}: 0.97\right)$ throughout the experimental period (293 days). This comparison points out that the manometric method is mainly appropriate for the description of medium to long term mineralization. Short-term events of decomposition (that occur mainly until the end of the $1^{\text {st }}$ month), such as, leaching, and oxidations of labile compounds (Bianchini Júnior \& Cunha-Santino, 2011), can be well described by specific short-term experiments.

The results obtained with the use of this method are important to demonstrate that even though it is simple, numerous events related to mineralization could be adequately addressed. This method is particularly valuable for the systemic comparison of the several organic resource mineralizations and for the primary measurement of the main parameters involved. This method combined with simple experiments (such as: litter bags, kinetic assessments) can greatly improve the understanding of the cycling of organic resources in aquatic environments or hydric soils.

\section{Acknowledgements}

The authors would like to thank the São Paulo Research Foundation (FAPESP process $n^{\circ}$ : 2007/08602-9), and the Brazilian National Council for Scientific and Technological Development for 
the scholarship (CNPq process $n^{\circ} 306264 / 2020$ $0)$. We are also indebted to Dr. João H.P. Dias and Dr. Norberto C. Vianna (Companhia Energética de São Paulo - CESP) for their assistance in obtaining water samples and plant resources.

\section{References}

ANTONIO, R.M. and BIANCHINI JÚNIOR, I. Fatores ambientais e formação de gases dos sedimentos da lagoa do Infernáo. In: J.E. SANTOS and J.S.R. PIRES, eds. Estudos integrados em ecossistemas - estação ecológica de jataí. São Carlos: Rima, 2000, pp. 695-706, vol. 2.

BÄRLOCHER, F. Leaching. In: M.A.S. GRAÇA, F. BÄRLOCHER and M. GESSNER, eds. Methods to study litter decomposition: a practical guide. Dordrecht: Springer, 2005b, pp. 33-36. http://dx.doi. org/10.1007/1-4020-3466-0_5.

BÄRLOCHER, F. Leaf mass loss estimated by litter bag technique. In: M.A.S. GRAÇA, F. BÄRLOCHER and M. GESSNER, eds. Methods to study litter decomposition: a practical guide. Dordrecht: Springer, 2005a, pp. 37-42. http://dx.doi.org/10.1007/14020-3466-0_6.

BÄRLOCHER, F. Pitfalls of traditional techniques when studying decomposition of vascular plant remains in aquatic habitats. Limnetica, 1997, 13, 1-11.

BASHKIN, V.N. Modern biogeochemistry. Dordrecht: Kluwer Academic Publishers, 2002.

BIANCHINI JÚNIOR, I. and ANTONIO, R.M. Formação anaeróbia de gases dos sedimentos da lagoa do Infernão e do reservatório do Monjolinho. In: J.E. SANTOS and J.S.R. PIRES, eds. Estudos integrados em ecossistemas - estação ecológica de jataí. São Carlos: Rima, 2000, pp. 685-694.

BIANCHINI JÚNIOR, I. and CUNHA-SANTINO, M.B. Model parameterization for aerobic decomposition of plant resources drowned during man-made lakes formation. Ecologcal Modelling, 2011, 222(7), 1263-1271.

BIANCHINI JÚNIOR, I. and CUNHA-SANTINO, M.B. The effect of the size of particles on mineralization of Oxycaryum cubense (Poepp. \& Kunth) Lye. Brazilian Journal of Biology $=$ Revista Brasileira de Biologia, 2006, 66(2b), 641-650.

BIANCHINI JÚNIOR, I. Modelos de crescimento e decomposição de macrófitas aquáticas. In: S.M. TOMAZ and L.M. BINI, eds. Ecologia e Manejo de Macrófttas Aquáticas. Maringá: EdUEM, 2003, pp. 85-126.

BIANCHINI JÚNIOR, I., ANTONIO, R.M. and MOURA, L.F. On the manometric method for estimating the anaerobic mineralization in aquatic ecosystems: kinetic and methodological aspects. Brazilian Journal of Microbiology, 1997, 28, 83-90, Supplement 1.
BOWIE, G.L., MILLS, W.B., PORCELLA, D.B., CAMPBELL, C.L., PAGENKOPF, J.R., RUPP, G.L., JOHNSON, K.M., CHAN, P.W.H., GHERINI, S.A. and CHAMBERLIN, C.E. Rates, constants, and kinetics formulations in surface water quality modeling - EPA/600/3-85/040. 2nd ed. Washington, DC: US Environmental Protection Agency, 1985.

CHAPMAN, S.K., HAYES, M.A., KELLY, B. and LANGLEY, J.A. Exploring the oxygen sensitivity of wetland soil carbon mineralization. Biology Letters, 2019, 15(1), 20180407. http://dx.doi.org/10.1098/ rsbl.2018.0407. PMid:30958210.

CUNHA-SANTINO, M.B. and BIANCHINI JÚNIOR, I. Effects of detritus chemical composition on the anaerobic mineralization of Salvinia auriculata and Utricularia breviscapa. Acta Limnologica Brasiliensia, 2015, 27(2), 202-212. http://dx.doi. org/10.1590/S2179-975X2913.

CUNHA-SANTINO, M.B. and BIANCHINI JÚNIOR, I. The aerobic and anaerobic decomposition of Typha domingensis Pers. Acta Limnologica Brasiliensia, 2006, 18(3), 321-334.

CUNHA-SANTINO, M.B., BITAR, A.L. and BIANCHINI JÚNIOR, I. Gas emission from anaerobic decomposition of plant resources. Acta Limnologica Brasiliensia, 2016, 28(0), e30. http:// dx.doi.org/10.1590/s2179-975x1616.

CUNHA-SANTINO, M.B., PACOBAHYBA, L.D. and BIANCHINI JÚNIOR, I. Decomposition of aquatic macrophytes from Cantá Stream (Roraima, Brazil): kinetics approach. Acta Limnologica Brasiliensia, 2010, 22(2), 237-246. http://dx.doi.org/10.1590/ S2179-975X2010000200012.

DALMAGRO, H.J., JOHNSON, M.S., MUSIS, C.R., LATHUILLIÈRE, M.J., GRAESSER, J., PINTO-JÚNIOR, O.B. and COUTO, E.G. Spatial patterns of DOC concentration and DOM optical properties in a Brazilian tropical riverwetland system. Journal of Geophysical Research. Biogeosciences, 2017, 122(8), 1883-1902. http:// dx.doi.org/10.1002/2017JG003797.

FONSECA, A.L.S., BIANCHINI JÚNIOR, I., PIMENTA, C.M.M., MANGIAVACCHI, N. and SOARES, C.B.P. Kinetics of aerobic decomposition in the leaching phase of allochthonous plant detritus. Acta Limnologica Brasiliensia, 2014, 26(1), 89-97. http://dx.doi.org/10.1590/S2179975X2014000100010.

GREEN, S.J., PRAKASH, O., GIHRING, T.M., AKOB, D.M., JASROTIA, P., JARDINE, P.M., WATSON, D.B., BROWN, S.D., PALUMBO, A.V. and KOSTKA, J.E. Denitrifying bacteria isolated from terrestrial subsurface sediments exposed to mixed-waste contamination. Applied and Environmental Microbiology, 2010, 76(10), 3244- 
3254. http://dx.doi.org/10.1128/AEM.03069-09. PMid:20305024.

HEITKAMP, F., JACOBS, A., JUNGKUNST, H.F., HEINZE, S., WENDLAND, M. and KUZYAKOV, Y. Processes of soil carbon dynamics and ecosystem carbon cycling in a changing world. In: R. LAL, K. LORENZ, R.F. HÜTTL, B.U. SCHNEIDER and J. VON BRAUN, eds. Recarbonization of the biosphere: ecosystems and the global carbon cycle. Dordrecht: Springer, 2012, pp. 395-428. http:// dx.doi.org/10.1007/978-94-007-4159-1_18

INTERGOVERNMENTAL PANEL ON CLIMATE CHANGE - IPCC. 2013 Supplement to the 2006 IPCC Guidelines for National Greenhouse Gas Inventories: Wetlands. Switzerland: IPCC, 2014.

INTERGOVERNMENTAL PANEL ON CLIMATE CHANGE - IPCC. 2019 Refinement to the 2006 IPCC Guidelines for National Greenhouse Gas Inventories. Switzerland: IPCC, 2019.

JENNY, H., GESSEL, S.P. and BINGHAM, F.T. Comparative study of decomposition rates of organic matter in temperate and tropical regions. Soil Science, 1949, 68(6), 419-432. http://dx.doi. org/10.1097/00010694-194912000-00001.

LANGMUIR, D. Aqueous environmental geochemistry. Upper Saddle River: Prentice Hall, 1997.

LITTLE, E.C.S. Handbook of utilization of aquatic plants - Fisheries Technical Paper No. 187 (FIRI/T187). Rome: FAO, 1979.

MEGONIGAL, J.P., HINES, M.E. and VISSCHER, P.T. Anaerobic metabolism: linkages to trace gases and aerobic processes. In: W.H. SCHLESINGER, ed. Biogeochemistry. Oxford: Elsevier-Pergamon, 2004, pp. 317-424

OHLE, W. Measuring the evolution rate of gases in bottom sediment. In: Y.I. SOROKIN and H. KADOTA, eds. Techniques for the assessment of microbial production and decomposition in fresh water $I B P n^{\circ}$ 23. Oxford: Blackwell, 1972, pp. 29-33.

PASSERINI, M.D., CUNHA-SANTINO, M.B. and BIANCHINI JÚNIOR, I. Oxygen availability and temperature as driving forces for decomposition of aquatic macrophytes. Aquatic Botany, 2016, 130, 1-10. http://dx.doi.org/10.1016/j.aquabot.2015.12.003.

PHILBEN, M., ZHANG, L., YANG, Z., TAŞ, N., WULLSCHLEGER, S.D., GRAHAM, D.E. and GU, B. Anaerobic respiration pathways and response to increased substrate availability of Arctic wetland soils. Environmental Science: Processes \& Impacts, 2020, 22(10), 2070-2083. http://dx.doi. org/10.1039/D0EM00124D. PMid:33084697.

REDDY, K.R. and DELAUNE, R.D. Biochemistry of wetlands - science and applications. Boca Raton: CRC Press, 2008. http://dx.doi. org/10.1201/9780203491454.

SANDERMAN, J. and AMUNDSON, R. Biogeochemistry of decomposition and detrital processing. In: W.H. SCHLESINGER ed. Biogeochemistry. Oxford: Elsevier-Pergamon, 2004. pp. 249-316.

SAUNDERS, G.W. Decomposition in fresh water. In: J.M. ANDERSON and A. MACFADYEN eds. The role of terrestrial and aquatic organisms in decomposition processes. Oxford: Blackwell, 1976, pp. 341-373.

SILVA, D.S., CUNHA-SANTINO, M.B., MARQUES, E.E. and BIANCHINI JÚNIOR, I. The decomposition of aquatic macrophytes: bioassays versus in situ experiments. Hydrobiologia, 2011, 665(1), 219-227. http://dx.doi.org/10.1007/s10750011-0625-4.

STEINBERG, C.E.W. Ecology of humic substances in freshwaters: determinants from geochemistry to ecological niches. Berlin: Springer, 2003. http://dx.doi. org/10.1007/978-3-662-06815-1.

SWIFT, M.J., HEAL, O.W. and ANDERSON, J.M. Decomposition in terrestrial ecosystems. Oxford: Blackwell, 1979.

YAN, J., WANG, L., HU, Y., TSANG, Y.F., ZHANG, Y., WU, J., FU, X. and SUN, Y. Plant litter composition selects different soil microbial structures and in turn drives different litter decomposition pattern and soil carbon sequestration capability. Geoderma, 2018, 319, 194-203. http://dx.doi. org/10.1016/j.geoderma.2018.01.009.

YARWOOD, S.A. The role of wetland microorganisms in plant-litter decomposition and soil organic matter formation: a critical review. FEMS Microbiology Ecology, 2018, 94(11), fiy175. http://dx.doi.org/10.1093/femsec/fiy 175 . PMid:30169564.

Received: 09 April 2021 Accepted: 16 August 2021

Associate Editor: André Megali Amado. 